\title{
NEW RADIOCARBON DATES OF THE NORTH ASIAN STEPPE ZONE AND ITS CONSEQUENCES FOR THE CHRONOLOGY
}

\author{
Jochen Görsdorf ${ }^{1} \bullet$ Hermann Parzinger • Anatoli Nagler \\ German Institute of Archaeology, Eurasian-Department, P.O. Box 3300 14, D-14191 Berlin, Germany
}

ABSTRACT. The chronological problems of the Steppe zone have been under intensive investigation during the last years but no generally accepted chronological system existed up to now. We present new radiocarbon dates of samples from several excavation sites. The dates allow a comparison of the Bronze Age development in the Siberian Steppe Zone with other neighboring regions.

\section{INTRODUCTION}

We have been working in the cemeteries of Suchanicha, Potroshilovo, and Bajkara collecting samples for radiocarbon dating. Together with data gathered at the Okunev sites of Čebaki and Ujbat, and a Bainov-sample from Krivaja, these samples give us new absolute dates for different Bronze Age cultures. They include Afanas'evo, Okunev, Andronovo, and Karasuk (classical Karasuk and Kamennyj Log phase) as well as the Scythian culture, the early Bainov, and the late Tes' phase of the Tagar culture-the later related with the Huns. Presented dating is a continuation of the Cupertino project performed in collaboration with the ${ }^{14} \mathrm{C}$ laboratory and specialists of the Institute of the History of Material Culture of Russian Academy of Sciences (St Petersburg) to investigate chronological problems of the South Russian and Siberian Steppe Zone.

\section{METHODS}

Chemical pretreatment of wood and charcoal samples was done with A-A-A treatment (Mook and Streurman 1983). The procedure for separating the collagen fraction of bones was done essentially according to Longin and Olsson (Longin 1970; Olsson et al. 1974). Dating was performed with gas proportional counters of the Houtermans-Oeschger type, using methane at $133.3 \mathrm{kPa}$ pressure as a filling gas. Measurement control and data processing were achieved with the help of computers (Görsdorf 1990; Görsdorf and Bojadžev 1996). Since 1997 (Bln-4977) a modern electronic measurement has been used. Preamplifier, pulse amplifier, comparator, pulse shaper, and anti-coincidence are located in a box $(19 \mathrm{~cm} \times 10 \mathrm{~cm} \times 5 \mathrm{~cm})$, which is directly connected to the counter. Detection of variation in the environmental radiation and inspection of the long-time stability of the electronics were required in order to reach measurement accuracy (Görsdorf 2000). The $\delta^{13} \mathrm{C}$-measurements were done by $\mathrm{H}$ Erlenkeuser and colleagues (Leibniz-Labor, University of Kiel) and are reported with respect to PDB-standard.

\section{RESULTS}

The tree ring count of charcoal and wood samples could not be determined. In the calibration program OxCal v3.4 (Ramsey 1995, 2000) we used the decadal calibration curve (Stuiver et al. 1998) as a first approximation for all samples. The calibration intervals were presented with confidence of $68.2 \%$ in a 10 -year rounded form. The following table shows the dating results and locations:

\footnotetext{
${ }^{1}$ Corresponding author. Email: 14C@ dainst.de

(C) 2001 by the Arizona Board of Regents on behalf of the University of Arizona Radiocarbon, Vol 43, Nr 2B, 2001, p 1115-1120

Proceedings of the 17 th International ${ }^{14} \mathrm{C}$ Conference, edited by I Carmi and E Boaretto
} 


\begin{tabular}{|c|c|c|c|}
\hline \multicolumn{4}{|c|}{ Ujbat $\left(53^{\circ} 43^{\prime} 31^{\prime \prime} \mathrm{N}, 90^{\circ} 22^{\prime} 16^{\prime \prime} \mathrm{E}\right)$} \\
\hline $\begin{array}{l}\text { Bln-5196 } \\
\text { human bone }\end{array}$ & $\begin{array}{l}\text { burial mound } 1 \text {, grave } 4 \text {, } \\
\text { Okunev culture }\end{array}$ & $-19.5 \%$ & $\begin{array}{l}\mathbf{4 0 1 6} \pm \mathbf{3 0} \mathbf{B P} \\
2580-2470 \mathrm{cal} \mathrm{BC}\end{array}$ \\
\hline $\begin{array}{l}\text { Bln-5195 } \\
\text { human bone }\end{array}$ & $\begin{array}{l}\text { burial mound } 1 \text { grave } 1 \text {, } \\
\text { Okunev culture }\end{array}$ & $-19.5 \%$ & $\begin{array}{l}\mathbf{3 7 3 4} \pm \mathbf{2 9} \mathbf{B P} \\
2200-2160 \mathrm{cal} \mathrm{BC} \\
2150-2120 \mathrm{cal} \mathrm{BC} \\
2090-2040 \mathrm{cal} \mathrm{BC}\end{array}$ \\
\hline \multicolumn{4}{|c|}{ Potroshilovo $\left(53^{\circ} 54^{\prime} 14^{\prime \prime} \mathrm{N}, 91^{\circ} 33^{\prime} 15^{\prime \prime} \mathrm{E}\right)$} \\
\hline $\begin{array}{l}\text { Bln-5163 } \\
\text { human bone }\end{array}$ & $\begin{array}{l}\text { enclosure } 5, \text { grave } 1 \\
\text { Andronovo culture }\end{array}$ & $-19.3 \%$ & $\begin{array}{l}\mathbf{3 3 9 7} \pm \mathbf{3 0} \text { BP } \\
1740-1680 \text { cal BC } \\
1670-1630 \text { cal BC }\end{array}$ \\
\hline $\begin{array}{l}\text { Bln-5194 } \\
\text { human bone }\end{array}$ & $\begin{array}{l}\text { grave } 7 \\
\text { Andronovo culture }\end{array}$ & $-20.4 \% o$ & $\begin{array}{l}\mathbf{3 2 9 5} \pm \mathbf{3 2} \text { BP } \\
1610-1520 \mathrm{cal} \mathrm{BC}\end{array}$ \\
\hline $\begin{array}{l}\text { Bln-5198 } \\
\text { human bone }\end{array}$ & $\begin{array}{l}\text { enclosure } 5 \text {, grave } 2 \\
\text { Andronovo culture }\end{array}$ & $-20.1 \%$ & $\begin{array}{l}\mathbf{3 2 6 9} \pm \mathbf{2 8} \mathbf{B P} \\
1610-1510 \mathrm{cal} \mathrm{BC}\end{array}$ \\
\hline $\begin{array}{l}\text { Bln-5197 } \\
\text { human bone }\end{array}$ & $\begin{array}{l}\text { grave } 11 \\
\text { Andronovo culture }\end{array}$ & $-19.7 \%$ & $\begin{array}{l}\mathbf{3 1 8 9} \pm \mathbf{2 8} \mathbf{B P} \\
1500-1420 \mathrm{cal} \mathrm{BC}\end{array}$ \\
\hline $\begin{array}{l}\text { Bln-5193 } \\
\text { human bone }\end{array}$ & $\begin{array}{l}\text { grave } 20 \\
\text { Andronovo culture }\end{array}$ & $-19.7 \%$ & $\begin{array}{l}\mathbf{3 1 6 4} \pm \mathbf{2 8} \mathbf{B P} \\
1500-1470 \mathrm{cal} \mathrm{BC} \\
1460-1400 \mathrm{cal} \mathrm{BC}\end{array}$ \\
\hline $\begin{array}{l}\text { BIn-5164 } \\
\text { human bone }\end{array}$ & $\begin{array}{l}\text { grave } 7 \\
\text { "classical" Karasuk culture }\end{array}$ & $-17.7 \%$ & $\begin{array}{l}\mathbf{2 9 9 4} \pm \mathbf{2 6} \mathbf{B P} \\
1300-1190 \mathrm{cal} \mathrm{BC} \\
1180-1160 \mathrm{cal} \mathrm{BC} \\
1150-1130 \mathrm{cal} \mathrm{BC}\end{array}$ \\
\hline $\begin{array}{l}\text { Bln-5165 } \\
\text { human bone }\end{array}$ & $\begin{array}{l}\text { grave } 1 \\
\text { "classical" Karasuk culture }\end{array}$ & $-15.4 \%$ & $\begin{array}{l}\mathbf{2 9 0 5} \pm \mathbf{2 6} \mathbf{B P} \\
1190-1180 \mathrm{cal} \mathrm{BC} \\
1130-1020 \mathrm{cal} \mathrm{BC}\end{array}$ \\
\hline \multicolumn{4}{|c|}{ Krivaja $\left(53^{\circ} 33^{\prime} 27^{\prime \prime} \mathrm{N}, 91^{\circ} 39^{\prime} 16^{\prime \prime} \mathrm{E}\right)$} \\
\hline $\begin{array}{l}\text { Bln-5166 } \\
\text { human bone }\end{array}$ & $\begin{array}{l}\text { grave } 1 \\
\text { Tagar culture }\end{array}$ & $-15.6 \%$ & $\begin{array}{l}\mathbf{2 5 5 2} \pm \mathbf{3 2} \text { BP } \\
800-760 \text { cal BC } \\
690-660 \text { cal BC } \\
630-590 \text { cal BC } \\
580-560 \text { cal BC }\end{array}$ \\
\hline \multicolumn{4}{|c|}{ Bajkara $\left(53^{\circ} 53^{\prime} 37^{\prime \prime} \mathrm{N}, 67^{\circ} 25^{\prime} 20^{\prime \prime} \mathrm{E}\right)$} \\
\hline $\begin{array}{l}\text { Bln-5031 } \\
\text { wood }\end{array}$ & $\begin{array}{l}\text { burial mound } 4 \text {, grave } \\
\text { Andronovo culture }\end{array}$ & $-25.6 \%$ & $\begin{array}{l}\mathbf{3 4 0 8} \pm \mathbf{3 7} \mathbf{B P} \\
1750-1630 \mathrm{cal} \mathrm{BC}\end{array}$ \\
\hline $\begin{array}{l}\text { Bln-5032 } \\
\text { wood }\end{array}$ & $\begin{array}{l}\text { burial mound } 2 \text { grave } 3 \\
\text { Andronovo culture }\end{array}$ & $-26.3 \%$ & $\begin{array}{l}\mathbf{3 3 4 6} \pm \mathbf{4 2} \mathbf{B P} \\
1690-1600 \mathrm{cal} \mathrm{BC} \\
1570-1530 \mathrm{cal} \mathrm{BC}\end{array}$ \\
\hline $\begin{array}{l}\text { BIn-5200 } \\
\text { human bone }\end{array}$ & $\begin{array}{l}\text { burial mound } 2 \text { grave } 2 \\
\text { Andronovo culture }\end{array}$ & $-20.0 \%$ & $\begin{array}{l}\mathbf{3 2 7 9} \pm \mathbf{2 8} \mathbf{B P} \\
1610-1510 \mathrm{cal} \mathrm{BC}\end{array}$ \\
\hline $\begin{array}{l}\text { Bln-5169 } \\
\text { human bone }\end{array}$ & $\begin{array}{l}\text { burial mound } 2 \text { grave } 1 \\
\text { Scythian }\end{array}$ & $-19.8 \%$ & $\begin{array}{l}\mathbf{2 5 0 6} \pm \mathbf{2 8} \mathbf{B P} \\
770-750 \mathrm{cal} \mathrm{BC} \\
690-540 \mathrm{cal} \mathrm{BC}\end{array}$ \\
\hline $\begin{array}{l}\text { Bln-5185 } \\
\text { human bone }\end{array}$ & $\begin{array}{l}\text { burial mound } 2 \text { grave } 1 \\
\text { Scythian }\end{array}$ & $-20.2 \%$ & $\begin{array}{l}\mathbf{2 4 9 6} \pm \mathbf{2 8} \mathbf{B P} \\
770-750 \mathrm{cal} \mathrm{BC} \\
770-540 \mathrm{cal} \mathrm{BC}\end{array}$ \\
\hline $\begin{array}{l}\text { Bln-5188 } \\
\text { human bone }\end{array}$ & $\begin{array}{l}\text { burial mound } 8 \text { grave } \\
\text { Scythian }\end{array}$ & $-20.6 \%$ & $\begin{array}{l}\mathbf{2 3 7 0} \pm \mathbf{2 9} \mathbf{B P} \\
510-390 \mathrm{cal} \mathrm{BC}\end{array}$ \\
\hline $\begin{array}{l}\text { Bln-5029 } \\
\text { birch bark }\end{array}$ & $\begin{array}{l}\text { burial mound } 1 \text {, trench } 1 / 3 \\
\text { Scythian }\end{array}$ & $-28.9 \%$ & $\begin{array}{l}\mathbf{2 3 3 8} \pm \mathbf{3 5} \text { BP } \\
480-470 \text { cal BC } \\
420-370 \text { cal BC } \\
270-260 \text { cal BC }\end{array}$ \\
\hline $\begin{array}{l}\text { Bln-5030 } \\
\text { wood }\end{array}$ & $\begin{array}{l}\text { burial mound } 1 \text {, trench } 3 / 5 \\
\text { Scythian }\end{array}$ & $-29.0 \%$ & $\begin{array}{l}\mathbf{2 3 4 3} \pm \mathbf{3 1} \mathbf{~ B P} \\
480-470 \text { cal BC } \\
420-380 \text { cal BC }\end{array}$ \\
\hline $\begin{array}{l}\text { Bln-5184 } \\
\text { charcoal }\end{array}$ & $\begin{array}{l}\text { burial mound } 1, \text { north, fire place } \\
\text { Sarmatian }\end{array}$ & $-26.7 \%$ & $\begin{array}{l}\mathbf{2 0 8 3} \pm \mathbf{2 6} \mathbf{B P} \\
160-130 \mathrm{cal} \mathrm{BC} \\
120-50 \mathrm{cal} \mathrm{BC}\end{array}$ \\
\hline $\begin{array}{l}\text { Bln-5187 } \\
\text { human bone }\end{array}$ & $\begin{array}{l}\text { burial mound } 1 \text {, grave } 1 \text {, skeleton } 1 \\
\text { Sarmatian }\end{array}$ & $-19.4 \%$ & $\begin{array}{l}\mathbf{2 0 8 1} \pm \mathbf{2 5} \mathbf{~ B P} \\
150-130 \mathrm{cal} \mathrm{BC} \\
120-40 \mathrm{cal} \mathrm{BC}\end{array}$ \\
\hline $\begin{array}{l}\text { Bln-5172 } \\
\text { human bone }\end{array}$ & $\begin{array}{l}\text { burial mound } 9 \text {, grave } \\
\text { Sarmatian }\end{array}$ & $-19.5 \%$ & $\begin{array}{l}1952 \pm 26 \mathbf{B P} \\
20-90 \text { cal AD }\end{array}$ \\
\hline $\begin{array}{l}\text { Bln-5199 } \\
\text { human bone }\end{array}$ & $\begin{array}{l}\text { burial mound } 1 \text {, grave } 2 \text {, skeleton } 2 \\
\text { robbery }\end{array}$ & $-19.1 \%$ & $\begin{array}{l}\mathbf{2 8 1} \pm \mathbf{2 4} \mathbf{B P} \\
1520-1560 \mathrm{cal} A D \\
1630-1660 \mathrm{cal} A D\end{array}$ \\
\hline $\begin{array}{l}\text { Bln-5028 } \\
\text { wood }\end{array}$ & $\begin{array}{l}\text { burial mound } 1 \text {, trench } 3 \\
\text { robbery }\end{array}$ & & $\begin{array}{l}\mathbf{2 2 4} \pm \mathbf{3 1} \mathbf{B P} \\
1640-1680 \mathrm{cal} \mathrm{AD} \\
1770-1800 \mathrm{cal} A D \\
1940-1950 \mathrm{cal} A D\end{array}$ \\
\hline
\end{tabular}




\section{COMMENTS AND CONCLUSIONS}

Figure 1 shows earlier published results (Görsdorf, Parzinger, Nagler, and Leont'ev 1998) together with the above-presented dates. Dates from Suchanicha, Potroshilovo, Čebaki, Ujbat, Krivaja and Doge Baary II can be considered as an important progress in the absolute dating of South Siberian cultures. From Suchanicha, for example, we now have 15 dates from the same site, which seems extremely interesting. Nevertheless, the results of these dates and their interpretation cause trouble when compared with the prevailing ideas on absolute chronology of South Siberian cultures (Vadeckaja 1986). That fact should not surprise, because all older dates published by specialists have mostly been uncalibrated (Semencov et al. 1969). But this also means that the dates presented in this paper can only be considered as a first step and must be followed by many more dates from South Siberia and neighboring regions to solve the still existing chronological problems.

The earliest graves from the extensive cemetery of Suchanicha on the eastern shore of the river Jenisej and North of Minusinsk belong to the Afanas' evo culture dated for between the middle of 3rd and the beginning of the 2nd millennium BC (Vadeckaja 1986, 11-26). The calibrated dates from Suchanicha, however, speak for quite an earlier chronological position of this culture (Figure 1): they mostly belong to the first half of the 3rd millennium $\mathrm{BC}$, one of them even going back to the end of the 4th millennium BC (Bln-4764).

In general, Afanas'evo is followed by the Okunev culture. We are able to present two new Okunev dates from Ujbat. All dates of the Okunev culture from Čebaki and Ujbat V (Görsdorf, Parzinger, Nagler and Leont'ev 1998) fit quite well in this new tendency of higher dating of South Siberian cultures. Okunev was considered to start around $1800 \mathrm{BC}$ and to end around the middle of the 2nd millennium BC (Vadeckaja 1986:27-40). But six new dates, from graves (Ujbat V) as well as from a hillfort-like settlement or sanctuary (Čebaki), show the same result: they all belong to the last third of the 3rd millennium BC, reaching the very beginning of 2nd millennium BC (Figure 1).

Five new dates for the Andronovo culture come from the Potroshilovo graveyard, which is not too far from Suchanicha. These dates clearly show that the "classical" Andronovo phase (Fedorovka phase) follows Okunev and mainly belongs to the first half of the 2nd millennium BC. The transition between Okunev and Andronovo-Fedorovka should be somewhere in the first third of the 2nd millennium BC. In case of the chronological relation between Andronovo-Fedorovka and "classical" Karasuk our dates again show a sequence. At the moment it seems that the Karasuk culture follows Andronovo-Fedorovka and the transition should occur after the middle of the 2nd millennium BC. Nevertheless, we do not have enough dates for "classical" Karasuk (only two from Potroshilovo graveyard) to solve this chronological problem.

The six Karasuk dates from Suchanicha (Figure 1) represent the so called "Kamennyj Log phase" of that culture. There has been a long discussion on the chronological position of Kammenyj Log; some scholars consider it to date back to early Karasuk, others (the majority) to late Karasuk or even as a kind of transition to early Tagar (Leont'ev, Parzinger, Nagler 1996:175-204). If Kamennyj Log really represents late Karasuk and the transition to early Tagar, then the above presented dates-that with the exception of Bln 4763 date mostly to the last two centuries of the 2nd millennium BC-are a big surprise. The last third of the 2nd millennium BC is the time of the late Shang dynasty (Anyang), as historical dates as well as new Chinese ${ }^{14} \mathrm{C}$ dates prove (Lin Yün 1986:242). The relation between Anyang and Karasuk, however, is out of question. In any case, the problem is still not definitely solved. It depends also on the interpretation of Kamennyj Log, especially in relation to Karasuk, which is rather an archaeological problem. Taking into account the dates from Potroshilovo and Suchanicha presented above, it seems that "classical" Karasuk and Kamennyj Log are almost contemporaneous 


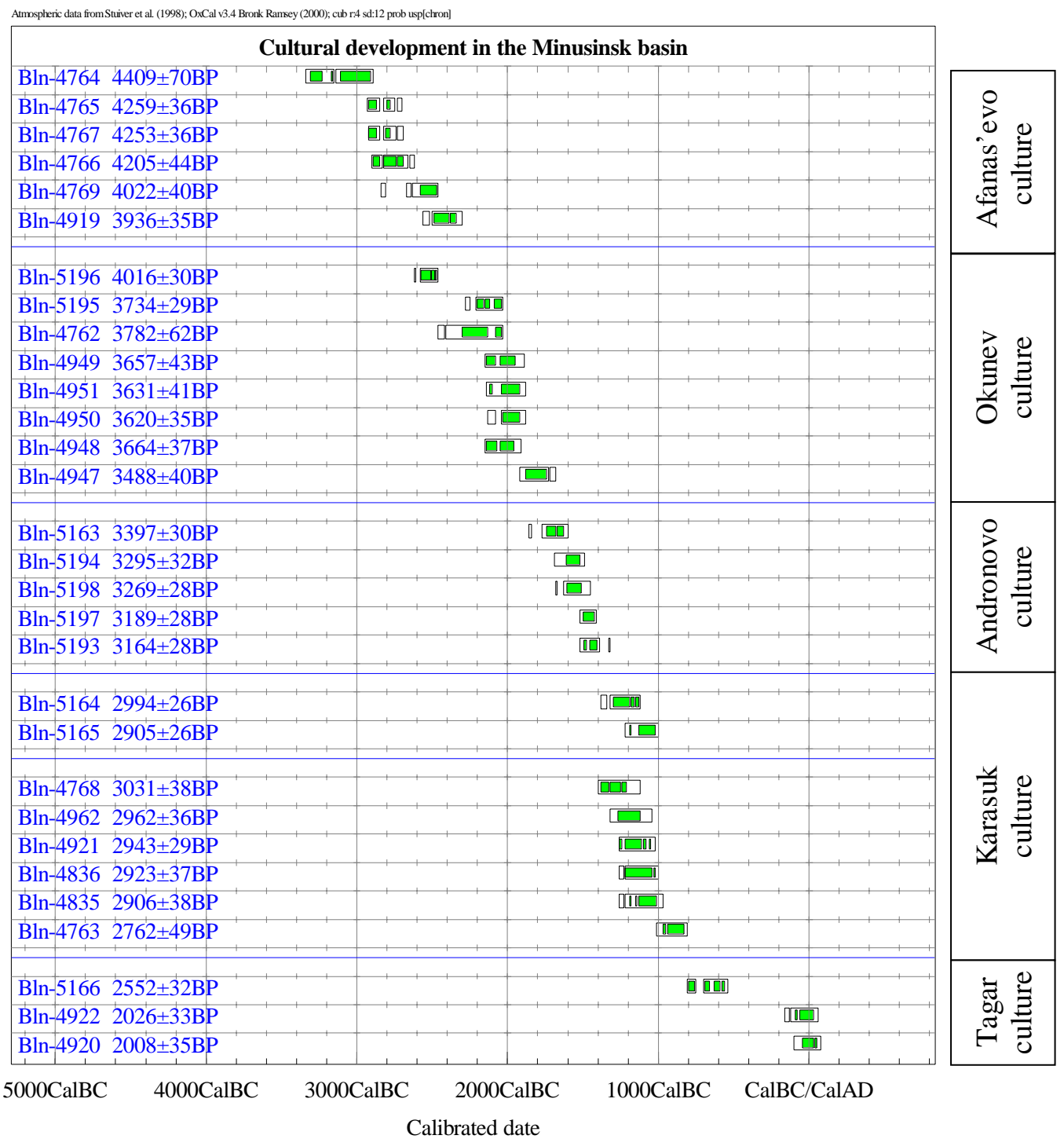

Figure 1 Cultural development in the Minusinsk basin

during the last three to four centuries of the 2 nd millennium BC. If future dates prove this result, then Karasuk and Kamennyj Log should be considered as different cultures that existed at the same time within the Minusinsk basin. But in that case, one has to check the archaeological definitions for both of them-quite a complicated topic - that cannot be treated here in detail.

One date from Krivaja is of special importance. It is a new date for the Bainov phase-the earliest phase of the Tagar culture in the Minusinsk basin that may be considered to belong more or less to the so called early Scythian Arzan horizon, or maybe slightly younger. The date presented above fits quite well into our chronological framework following the youngest Kamennyj Log dating from Suchanicha. This would mean that the transition between Kamennyj Log and the earliest Tagar culture should 
have taken place at the latest in the 9th century BC. However, we have to wait for further dates to be certain.

The youngest dates from Suchanicha belong to the latest phase of the Tagar culture, the so called Tes' phase, that Russian scholars always considered to represent the Huns mentioned in Chinese annals for the last centuries BC in the north of their empire. The relative and also absolute chronology of that period is leaves many open questions. The Tes' phase of the Tagar culture has always been dated as the last two centuries BC (Vadeckaja 1986:129-56). But our three dates from graves in the Suchanicha graveyard are slightly younger (Figure 1).

Another interesting point for chronological investigation is the burial mound cemetery of Bajkara near Sergeevka (north of Kazachstan), about $1600 \mathrm{~km}$ west of the Minusinsk basin. We dated a set of samples from this site (Figure 2). The dates of the Andronovo culture point to about the same age as the ones in the Minusinsk basin. The dates of scythian and sarmatian graves in Bajkara give us time marks for the use of the graveyard in the second half of the first millennium $\mathrm{BC}$ and the first centuries AD. The two young dates determine the time of robbery in the mound cemetery of Bajkara.

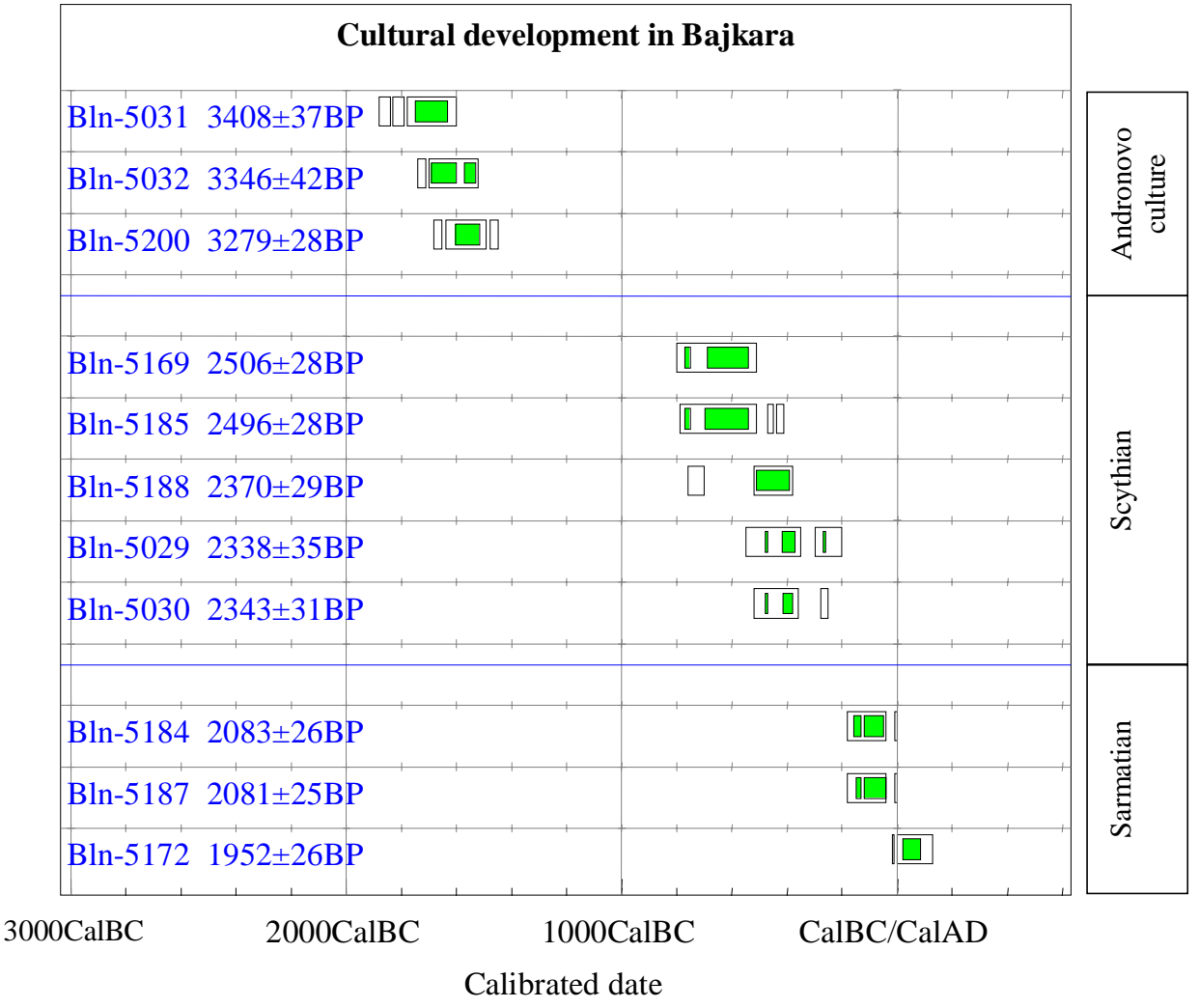

Figure 2 Cultural development in the excavation site Bajkara 
It was our aim to show that the absolute chronology of most of the South Siberian cultures still is not at all sure. Thanks to new ${ }^{14} \mathrm{C}$ dates we have to get used to the idea of higher chronology for most of these cultures. For example, the high age of the Afanas'evo culture in the Siberian Steppe contradicts the often expressed opinion that the pit grave culture spread from west to east. Discussion based on uncalibrated dates is completely useless and anachronistic. That also means breakup with most of the traditional chronological points of view. The discussion is definitely continuing and the only solution is to collect as many samples for ${ }^{14} \mathrm{C}$ and dendrochronology as possible in order to get a much more complete, new set of dates.

\section{ACKNOWLEDGMENTS}

We thank A Gotlib, Abakan, I Lazaretov (St Petersburg) for providing samples from the Okunev sites of Čebaki and Ujbat; N Leont'ev (Minusinsk) added a Bainov-sample from Krivaja. We gratefully acknowledge Dr H Erlenkeuser and colleagues (Leibniz-Labor, University of Kiel) for $\delta^{13} \mathrm{C}$ measurements. Thanks are extended to E Lau and D Teckenburg for assistance in the preparation and measurement of the samples.

\section{REFERENCES}

Görsdorf J. 1990. Die Interpretation von ${ }^{14} \mathrm{C}$-Datierungen im Berliner ${ }^{14} \mathrm{C}$-Labor. Zeitschrift für Archäologie 24:27-34.

Görsdorf J, Bojadžiev J. 1996. Zur absoluten chronologie der bulgarischen Urgeschichte. Berliner ${ }^{14} \mathrm{C}$-Datierungen von bulgarischen archäologischen Fundplätzen. Eurasia Antiqua 2:105-73.

Görsdorf J. 2000. Datierungen im Berliner ${ }^{14} \mathrm{C}$-labor. Berliner Beiträge zur Archäometrie 17: 121-31.

Görsdorf J, Parzinger H, Nagler A, Leont'ev N. 1998. New radiocarbon dates from the Siberian Steppe Zone and ist consequences for the regional Bronze Age chronology. Actes du colloque "C14 Archéologie" 1998, Supplément 1999 de la Revue d'Archéométrie:305-9.

Görsdorf J, Parzinger H, Nagler A, Leont'ev N. 1998. Neue ${ }^{14} \mathrm{C}$-Datierungen für die Sibirische Steppe und ihre Konsequenzen für die regionale Bronzezeitchronologie. Eurasia Antiqua 4:73-80.

Leont'ev N, Parzinger H, Nagler A. 1996. Die russischdeutschen Ausgrabungen beim Berg Suchanicha am mittleren Enisej. Eurasia Antiqua 2:175-204.

Lin Yün. 1986. A reexamination of the relationship between bronzes of the Shang culture and of the Northern Zone. In: Chang KC, editor. Studies of Shang archaeology. London, New Haven.

Longin R. 1970. Extraction du collagéne des os fossiles pour leur datation par la méthode du carbonne 14 [Thesis]. University of Lyon.

Mook WG, Streurman HJ. 1983. Physical and chemical aspects of radiocarbon dating. Journal of the European Study Group on Physical, Chemical and Mathematical Techniques Applied to Archaeology. PACT 8:31-55.

Olsson IU, El-Daoushy MFAF, Abd-El-Mageed AI, Klasson M. 1974. A comparison of different methods for pretreatment of bones. Geol. Fören. Stockh. Förhandl. 96:171-81.

Ramsey CB. 1995. Radiocarbon calibration and analysis of stratigraphy: the OxCal program. Radiocarbon 37(2):425-30.

Ramsey CB. 2000. Internet version of the OxCal Program v.3.4.

Semencov A.A., Romanova EN, Doluchanov PM. 1969. Radiouglerodnye daty laboratorii LOIA. SA, H. 1: 251-61.

Stuiver M, Reimer PJ, Bard E, Beck JW, Burr GS, Hughen KA, Kromer B, McCormac FG, van der Plicht J, Spurk M. 1998. INTCAL98 radiocarbon age calibration, 24,000-0 cal BP. Radiocarbon 40(3):104183.

Vadeckaja EB 1986. Archeologièeskie pamjatniki v stepjach Srednego Eniseja. Leningrad. 